\title{
Purification and characterization of malate dehydrogenase from sheep liver (Ovis aries): Application in AST assay diagnostic kit
}

\author{
Doaa A. Darwish, Hassan M.M. Masoud", Mohamed M. Abdel-Monsef, Mohamed S. Helmy, Mahmoud A. Ibrahim \\ Molecular Biology Department, National Research Centre, El-Tahrir st., Dokki, Giza, Egypt.
}

\author{
ARTICLE INFO \\ Article history: \\ Received on: 18/10/2017 \\ Accepted on: 24/12/2017 \\ Available online: 27/02/2018 \\ Key words: \\ Malate dehydrogenase, $\mathrm{Pu}-$ \\ rification, Characterization, \\ Sheep liver, AST diagnostic \\ kit.
}

\begin{tabular}{l}
\hline ABSTRACT \\
Malate dehydrogenase enzyme is a major component in aspartate aminotransferase (AST) diagnostic kit that used in \\
diagnosis and monitoring of liver diseases. This study aimed at purification and characterization of MDH enzyme from \\
sheep liver for direct application in preparation of AST kit. Two malate dehydrogenase isoenzymes were resolved \\
from sheep liver by chromatography on DEAE-cellulose column, one major sheep liver MDH (SLMDH) and another \\
minor one. SLMDH was extracted and purified by ammonium sulfate fractionation and chromatographical separation \\
on anion exchanger and gel filtration resins. The purified sheep liver MDH specific activity is 6.7 units $/ \mathrm{mg}$ protein \\
representing 11.6 purification folds and $27.7 \%$ yield. The molecular mass of SLMDH intact protein is $68 \pm 1.6 \mathrm{kDa}$. \\
SLMDH turned out to be homogeneous and consists of two identical subunits of $34 \pm 1.2 \mathrm{kDa}$ each. The SLMDH \\
isoelectric point $(\mathrm{pI}$ ) value is estimated at $\mathrm{pH} 6.2$ and displayed its optimum activity at pH 9.6 and has Km value of \\
$1.4 \mathrm{mM}$ for NAD and $11 \mathrm{mM}$ for malate. $\mathrm{FeCl}_{2}, \mathrm{NiCl}_{2}$ and $\mathrm{ZnCl}_{2}$ inhibited the SLMDH activity. The purified SLMDH \\
is applied in the preparation of AST diagnostic kit that found sensitive and comparable with a commercially available \\
one.
\end{tabular}

\section{INTRODUCTION}

Malate dehydrogenase (MDH: EC 1.1.1.37) is widely distributed enzyme through living organisms that present in animals, plants and microorganisms and it is an essential enzyme in the central oxidative pathway. MDH is a catalyst in the oxidation process of malate to oxaloacetate and uses the reduced $\mathrm{NAD}^{+}$to $\mathrm{NADH}$ as a cofactor. MDH is one of the main enzymes in the tricarboxylic acid cycle (TCA) that performs significant metabolic part in aerobic energy producing pathways and in malate shuttle. In eukaryotes, $\mathrm{MDH}$ is present in two forms either mitochondrial or cytosolic according to their location (Fickenscher et al., 1987; Domenech et al., 1988; Minárik et al., 2002; Takahashi-Iñiguez et al., 2016). Malate dehydrogenases were also found in plants and some eukaryotes in different organelles as glyoxysomes, chloroplasts and peroxisomes (Gietl, 1992). In aerobic prokaryotic and eukaryotic organisms, the TCA cycle is the main oxidative

\footnotetext{
${ }^{*}$ Corresponding Author

Hassan Mohamed M. Masoud, Molecular Biology Department, National Research Centre, Postal code: 12622, El-Tahrir st., Dokki, Giza, Egypt. E-mail: hssnmasoud@yahoo.com
}

pathway (Sidhu et al., 2011). A main reaction of TCA cycle is the transformation between malate and oxaloacetate stimulated by $\mathrm{NAD}^{+}$or $\mathrm{NADP}^{+}$dependent malate dehydrogenases. In addition to their important metabolic role in aerobic energy production, they participate in different metabolic actions comprising aspartate biosynthesis, the malate-aspartate shuttle, gluconeogenesis and lipogenesis (Labrou and Clonis, 1997). MDH has other tasks inside cells (Molenaar et al., 1998) as participation in the reductive TCA cycle for oxidative stress protection by binding the free radicals and in transfer of substrates throughout the metabolic pathways (Wu et al., 2007). Also, MDH with malic enzyme and pyruvate carboxylase are participated in an antioxidative pathway converting the pro-oxidant NADH into the antioxidant NADPH (Singh et al., 2008). In some microorganisms, MDH enzyme can interact with other TCA cycle enzymes to increase the cycle activity as in Bacillus subtilis that interacts with isocitrate dehydrogenase and citrate synthase forming a metabolon (Meyer et al., 2011; Bartholomae et al., 2014) and in E. coli, it interacts with the respiratory chain complex I for the immediate transport of NADH (Amarneh and Vik, 2005). MDH activity is vigorously blocked by oxaloacetate and NADH excess (Langelandsvik 
et al., 1997; Thompson et al., 1998; Madern and Zaccai, 2004; Mendoza et al., 2009). Lactate dehydrogenase (LDH) and MDH enzymes are major components in aspartate aminotransferase (AST) diagnostic kit. This kit is very sensitive in the detection of AST enzyme concentration in blood, serum and plasma which is mainly utilized as a liver function marker test in diagnosis, monitoring and treating of hepatic diseases. The kinetic assay of AST for diagnostic purposes uses a combined reaction of $\mathrm{MDH}$, LDH and NADH (Henry, 1974; Tietz, 1976; Henry, 1984; Young, 1990). Therefore, the main aim of this study is purification, characterization and production of MDH enzyme from the sheep liver as locally available, safe and rich source for use in preparation of the AST diagnostic kit.

\section{MATERIALS AND METHODS}

\section{Liver tissues}

Six fresh sheep liver samples were obtained from different male individuals in a local slaughter-house and stored at $-40^{\circ} \mathrm{C}$.

\section{Chemicals}

L-Aspartic acid sodium salt, Bovine serum albumin (BSA), $\alpha$-Ketoglutaric acid sodium salt, Lactate dehydrogenase from rabbit muscle, $\beta$-Nicotinamide adenine dinucleotide reduced form (NADH), $\beta$-Nicotinamide adenine dinucleotide sodium salt (NAD), Malate sodium salt, Nitroblue tetrazolium chloride (NBT), Phenazine methosulfate (PMS), DEAE-cellulose, Sephacryl S-300, Protein molecular weight standards and chemicals for electrophoresis were purchased from Sigma-Aldrich Chemical Co. The other chemicals were of analytical grade.

\section{Assay of malate dehydrogense activity}

For assaying $\mathrm{MDH}$ activity, a reaction mixture contained $50 \mathrm{mM}$ glycine- $\mathrm{NaOH}$ buffer ( $\mathrm{pH} 9.6$ ), $3 \mathrm{mM}$ malate and 0.52 mM NAD was used. NADH increase at $340 \mathrm{~nm}$ was followed for 3 minutes and one MDH unit is defined as the amount of enzyme required to oxidize or reduce $1 \mu \mathrm{mol}$ coenzyme $\min ^{-1}$ (Nava et al., 2011).

\section{Malate dehydrogenase activity staining on polyacrylamide gels}

After electrophoresis, the gels were submerged in 100 $\mathrm{ml} 0.1 \mathrm{M}$ Tris- $\mathrm{HCl}, \mathrm{pH} 8$ containing $250 \mathrm{mg}$ malate sodium salt, 30 mg NAD, $25 \mathrm{mg}$ NBT and $2 \mathrm{mg}$ PMS. The gel was incubated in the staining solution in dark at $37^{\circ} \mathrm{C}$ until dark blue bands appear (Richardson et al., 1986).

\section{Extraction and purification of sheep liver malate dehydroge- nase}

\section{Preparation of crude extract}

All of the procedures were performed at $4^{\circ} \mathrm{C}$ unless stated otherwise. 10 grams of sheep liver were homogenized in $0.05 \mathrm{M}$ sodium phosphate buffer $\mathrm{pH} 7.4$ containing $10 \mathrm{mM}$ EDTA and $1 \mathrm{mM} \mathrm{MgCl}$ using Omni mixer homogenizer. Cell debris and insoluble materials were removed by centrifugation at $5000 \mathrm{xg}$ for $20 \mathrm{~min}$ and the supernatant was saved and designated as crude extract.

\section{Ammonium sulfate precipitation}

The crude extract was brought to $40 \%$ saturation by gradually adding solid $\left(\mathrm{NH}_{4}\right)_{2} \mathrm{SO}_{4}$, stirred for $30 \mathrm{~min}$ at $4{ }^{\circ} \mathrm{C}$ and centrifuged at $8000 \mathrm{xg}$ for $20 \mathrm{~min}$. The pellet of this step was discarded and the filtrate was brought to $80 \%\left(\mathrm{NH}_{4}\right)_{2} \mathrm{SO}_{4}$ saturation and the pellet was obtained by centrifugation at $12000 \mathrm{xg}$ for 30 min, dissolved in $0.02 \mathrm{M}$ sodium phosphate buffer $\mathrm{pH} 7.4$ and dialyzed against the same buffer $(3 \times 2 \mathrm{~L}$ buffer $)$.

\section{DEAE-cellulose column chromatography}

The ammonium sulfate fraction was chromatographed on DEAE-cellulose column previously equilibrated with $0.02 \mathrm{M}$ sodium Phosphate buffer $\mathrm{pH}$ 7.4. The proteins were eluted with stepwise $\mathrm{NaCl}$ gradient ranging from 0 to $1 \mathrm{M}$ prepared in the equilibration buffer. Fractions of $5 \mathrm{ml}$ were collected at a flow rate of $60 \mathrm{ml} /$ hour. Fractions containing MDH activity were pooled and concentrated by lyophilization.

\section{Sephacryl S-300 column chromatography}

The concentrated solution containing the MDH activity was applied onto a Sephacryl S-300 column. The column was equilibrated and developed with $0.02 \mathrm{M}$ sodium Phosphate buffer $\mathrm{pH} 7.4$ at a flow rate of $30 \mathrm{ml} /$ hour and $2 \mathrm{ml}$ fractions were collected.

\section{Electrophoretic analysis}

Native gel electrophoresis was carried out with $7 \%$ PAGE (Smith, 1969). SDS-PAGE was performed with $12 \%$ polyacrylamide gel (Laemmli, 1970). The subunit molecular weight of the purified MDH enzyme was determined by SDSPAGE (Weber and Osborn, 1969). Electrofocusing was performed according to O'Farrell (1975) and the isoelectric point $(p \mathrm{I})$ value was calculated from a calibration curve as described by Ubuka et al. (1987). Proteins were stained with $0.25 \%$ Coomassie Brilliant Blue R-250.

\section{Protein determination}

Protein content was determined by the dye binding assay method using bovine serum albumin (BSA) as a standard protein (Bradford, 1976).

\section{Construction of aspartate aminotransferase (AST) diagnostic kit}

The purified sheep liver MDH is used in the construction of AST diagnostic kit. The kit is composed of two reagents: (R1: $80 \mathrm{mM}$ Tris- $\mathrm{HCl}$ buffer $\mathrm{pH} 7.8,240 \mathrm{mM}$ L-aspartate, $900 \mathrm{IU} / \mathrm{L}$ $\mathrm{LDH}$ and $600 \mathrm{IU} / \mathrm{L} \mathrm{MDH})$ and (R2: $12 \mathrm{mM}$ 2-oxoglutarate and $0.18 \mathrm{mM}$ NADH) (Thomas, 1998).

\section{RESULTS AND DISCUSSION}

\section{Purification of sheep liver malate dehydrogenase (SLMDH)}

Malate dehydrogenase is a major component in aspartate aminotransferase (AST) diagnostic kit. This kit is very sensitive in the measurement of AST enzyme concentration in blood, serum and plasma which is mainly used as a liver function marker test in diagnosis, monitoring and treatment of liver diseases (Henry, 1974; Tietz, 1976; Henry, 1984; Young, 1990). The main aim of this study is purification, characterization and production of $\mathrm{MDH}$ 
enzyme from the sheep liver as locally available, safe and rich source for using in preparation of the AST diagnostic kit. The purification procedure of $\mathrm{MDH}$ from the sheep liver is very convenient since it involved ammonium sulfate fractionation, anion-exchanger DEAEcellulose resin chromatography and size-exclusion chromatography on Sephacryl S-300 resin. Different MDH purification methods were stated from rat liver by ion-exchange chromatography with affinity elution by NADH (Wiseman et al., 1991) and from chicken liver by ammonium sulfate precipitation, affinity chromatography on 5'AMP-Sepharose and Blue-Sepharose CL-6B columns (Gelpi et al., 1988). The purification procedure of sheep liver MDH is summarized in Table 1. The chromatographic pattern of sheep liver MDH on the DEAE-cellulose resin manifested the existence of a major MDH enzyme activity peak that designated SLMDH eluted with $0.0 \mathrm{M} \mathrm{NaCl}$ and one minor peak exhibited the MDH activity was resolved and eluted with $0.05 \mathrm{M} \mathrm{NaCl}$ (Figure 1a). The major peak fractions exhibiting MDH activity were collected, concentrated and placed onto a Sephacryl S-300 column (Figure 1b) which showed the appearance of one MDH enzyme activity peak. Next size-exclusion chromatography, the SLMDH specific activity was raised to 6.7 units/mg protein representing 11.6 folds purification and $27.7 \%$ output (Table 1). A wide range of purification fold and recovery percent for $\mathrm{MDH}$ were reported. MDH from rat liver had 566-folds with 32\% yield (Wiseman et al., 1991) and from chicken liver 225-fold with 47\% yield (Gelpi et al., 1988).
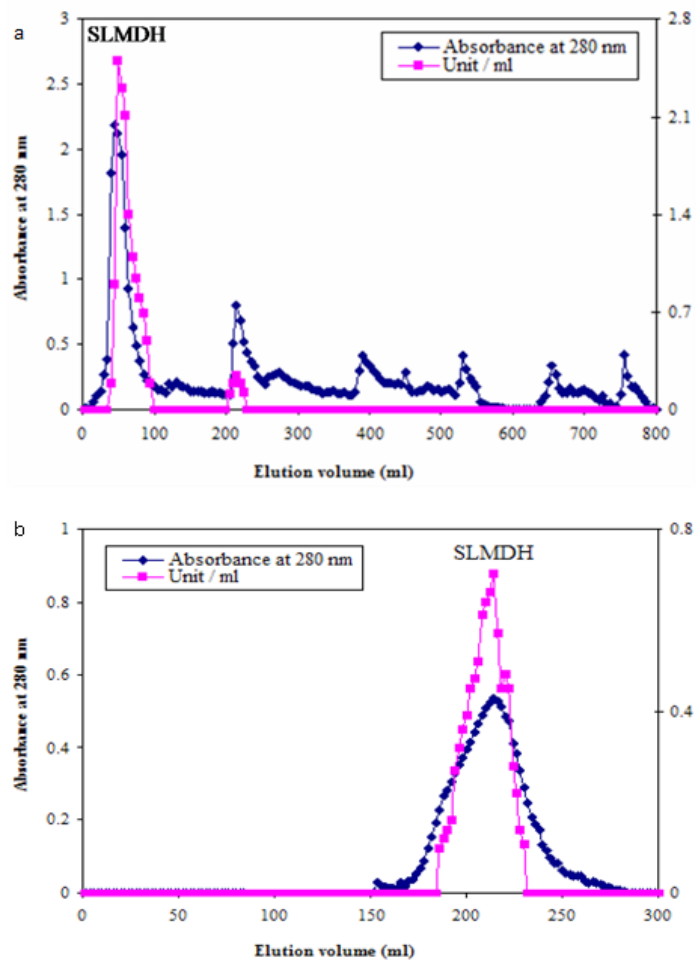

Fig. 1: (a) A typical elution profile for the chromatography of sheep liver ammonium sulfate fraction on DEAE-cellulose column $(6 \mathrm{~cm} \times 2.4 \mathrm{~cm}$ i.d. $)$ previously equilibrated $0.02 \mathrm{M}$ sodium phosphate buffer $\mathrm{pH}$ 7.4. (b) A typical elution profile for the chromatography of the sheep liver DEAE-cellulose fraction (SLMDH) on Sephacryl S-300 column $(142 \mathrm{~cm} \times 2.4 \mathrm{~cm}$ i.d.) previously equilibrated with $0.02 \mathrm{M}$ sodium phosphate buffer $\mathrm{pH} 7.4$.
Table 1: A typical purification scheme of the sheep liver malate dehydrogenas (SLMDH).

\begin{tabular}{lccccc}
\hline Purification steps & $\begin{array}{c}\text { Total } \\
\text { protein } \\
\text { (mg) }\end{array}$ & $\begin{array}{c}\text { Total } \\
\text { Activity } \\
\text { (unit) }\end{array}$ & $\begin{array}{c}\text { Specific } \\
\text { Activity }\end{array}$ & $\begin{array}{c}\text { Yield } \\
\text { (\%) }\end{array}$ & $\begin{array}{c}\text { Fold } \\
\text { Purifica- } \\
\text { tion }\end{array}$ \\
\hline $\begin{array}{l}\text { Sheep liver crude } \\
\text { extract }\end{array}$ & 384 & 224 & 0.58 & 100 & 1.0 \\
$\begin{array}{l}40-80 \%\left(\mathrm{NH}_{4}\right)_{2} \mathrm{SO}_{4} \\
\text { Fraction }\end{array}$ & 202 & 177 & 0.88 & 79 & 1.5 \\
$\begin{array}{l}\text { DEAE-cellulose } \\
\text { major fraction }\end{array}$ & 68 & 117 & 1.7 & 52.2 & 3.0 \\
$\begin{array}{l}\text { Sephacryl S-300 } \\
\text { fraction }\end{array}$ & 9.2 & 62 & 6.7 & 27.7 & 11.6 \\
\hline
\end{tabular}

\section{Molecular weight determination and electrophoretic analyses of SLMDH}

The native molecular weight of the prepared SLMDH is calculated from its elution volume on the gel filtration chromatography column to be $68 \pm 1.6 \mathrm{kDa}$ (Figure $1 \mathrm{~b}$ ). The purity of SLMDH isoenzyme eluted from the Sephacryl S-300 columns was investigated by analysis on 7\% native-PAGE. SLMDH isoenzyme displayed one protein band which corresponded with the MDH activity band affirming the tentative purity of the preparation (Figure $2 \mathrm{a}$ and $2 \mathrm{~b}$ ). The SLMDH subunit mass was resolved by SDS-PAGE which revealed that the SLMDH consists of two homodimer subunits with molecular weights of $34 \pm 1.2$ $\mathrm{kDa}$ each (Figure 2c). In consistent with SLMDH, MDH from Phytomonas sp. is a dimeric two subunits molecule of $37 \mathrm{kDa}$ each (Uttaro and Opperdoes, 1997), Pseudomonas stutzeri MDH molecular mass was $66.5 \mathrm{kDa}$ consisting of two subunits $34 \mathrm{kDa}$ each (Labrou and Clonis, 1997), MDH from the phototrophic bacterium, Rhodopseudomonas capsulata has molecular weight of $80 \mathrm{kDa}$ and consists of two subunits of $35 \mathrm{kDa}$ (Ohshima and Sakuraba, 1986) and MDH from leaves of the plant Aptenia cordifolia showed a subunit of $39.4 \mathrm{kDa}$ and a native mass of 83 kDa (Trípodi and Podestá, 2003). In contrast, MDH native protein of the bacterium Corynebacterium glutamicum was $130 \mathrm{kDa}$ which was homotetramer with 33-kDa subunit each (Genda et al., $2003)$. The isoelectric point $(p \mathrm{I})$ value of SLMDH was visualized on isoelectrofocusing PAGE as single species at $\mathrm{pH} 6.2$ (Figure 2d). Two MDH isoenzymes from Phytomonas $s p$. had $p$ I values of 6.0 and 7.2 (Uttaro and Opperdoes, 1997), MDH from rat liver with PI value of 5.2 (Wiseman et al., 1991) and MDH from leaves of the plant Aptenia cordifolia showed $p$ I value of 5.8 (Trípodi and Podestá, 2003).

\section{SLMDH optimum pH and Km value determination}

The $\mathrm{pH}$ optimum was studied by using glycine- $\mathrm{NaOH}$ buffer $\mathrm{pH}$ range of 8.6-10.6. The SLMDH enzyme optimum activity was detected at $\mathrm{pH} 9.6$ (Figure 3a). Analogously, the $\mathrm{pH}$ optimum was set at $\mathrm{pH} 9.5$ for $\mathrm{MDH}$ from the Phytomonas $s p$. (Uttaro and Opperdoes, 1997) and the phototrophic bacterium, Rhodopseudomonas capsulata (Ohshima and Sakuraba, 1986) while the bacterium Corynebacterium glutamicum MDH optimum activity was at $\mathrm{pH} 10.5$ (Genda et al., 2003). The Lineweaver-Burk plot for the reverse of the reaction velocity $(1 / \mathrm{v})$ and substrate concentration $(1 /[\mathrm{S}])$ indicated the value of $\mathrm{Km}$ to be $1.4 \mathrm{mM}$ for NAD (Figure $3 \mathrm{~b}$ ) and $11 \mathrm{mM}$ for sodium malate (Figure $3 \mathrm{c}$ ). The 
Km value of the Phytomonas sp $\mathrm{MDH}$ two isoforms for malate and NAD were 3 and $0.246 \mathrm{mM}$ for the first isoform and 0.45 and $0.091 \mathrm{mM}$ for the second isoform (Uttaro and Opperdoes, 1997). $\mathrm{Km}$ value of MDH from Pseudomonas stutzeri was 0.34 and 0.67 mM for NAD and malate respectively (Labrou and Clonis, 1997). The Km values of the phototrophic bacterium, Rhodopseudomonas capsulata $\mathrm{MDH}$ were $2.1 \mathrm{mM}$ malate and $48 \mu \mathrm{M}$ NAD (Ohshima and Sakuraba, 1986).
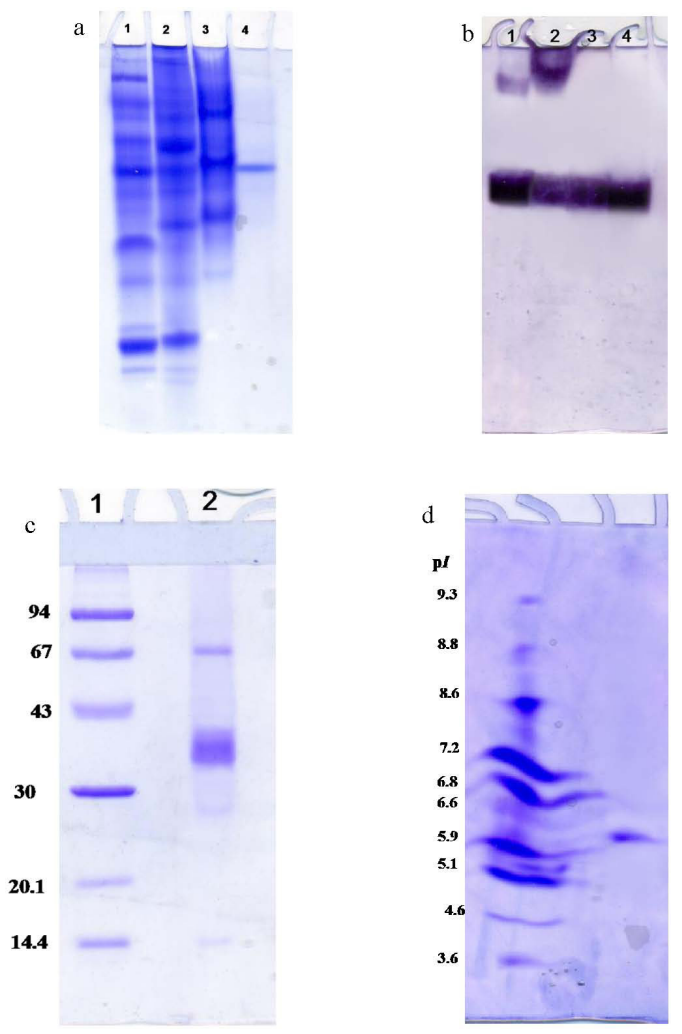

Fig. 2: (a) Electrophoretic analysis of protein pattern of SLMDH on 7\% native PAGE: (1) crude extract, (2) ammonium sulfate fraction, (3) DEAE-cellulose fraction and (4) Sephacryl S-300 purified fraction. (b) Electrophoretic analysis of isoenzyme pattern of SLMDH on 7\% native PAGE: (1) crude extract, (2) ammonium sulfate fraction, (3) DEAE-cellulose fraction and (4) Sephacryl S-300 purified fraction. (c) Subunit molecular weight determination of SLMDH by $12 \%$ SDS-PAGE: (1) Molecular weight marker proteins and (2) Purified SLMDH. (d) Isoelectrofocusing of SLMDH: (1) Isoelectric point ( $p I$ ) marker proteins and (2) The purified SLMDH.

\section{Effect of divalent cations and various inhibitors on SLMDH}

The effect of metal compounds on the purified SLMDH activity was examined. $\mathrm{FeCl}_{2}, \mathrm{NiCl}_{2}$ and $\mathrm{ZnCl}_{2}$ inhibited the purified sheep liver malate dehydrogenase (SLMDH) activity vigorously, while $\mathrm{CoCl}_{2}$ and $\mathrm{CuCl}_{2}$ inhibited SLMDH activity moderately
(Figure 4a). $\mathrm{Mg}^{2+}, \mathrm{Ca}^{2+}, \mathrm{Ni}^{2+}, \mathrm{Hg}^{2+}, \mathrm{Co}^{2+}$, and $\mathrm{Mn}^{2+}$ caused a weak inhibitory influence on the Phytomonas sp. MDH isoforms (Uttaro and Opperdoes, 1997). The ions $\mathrm{Zn}^{2+}, \mathrm{Mg}^{2+}, \mathrm{Mn}^{2+}, \mathrm{Cu}^{2+} ; \mathrm{Ni}^{2+}$ and $\mathrm{Co}^{2+}$ acted as inhibitors of the Mycobacterium phlei MDH (Tyagi et al., 1977). Also, the inhibition of purified SLMDH activity by several inhibitors was studied (Figure 4b). Pre-incubation of the inhibitors for 5 minutes with SLMDH at $37^{\circ} \mathrm{C}$ was carried out and the inhibition percent was deduced as a proportion of a noninhibited control. The purified SLMDH is inhibited with the serine protease inhibitor PMSF indicating that the active site of this isoenzyme contains a serine residue. Iodoacetamide inhibited the purified SLMDH isoenzyme activity which indicates that residues of methionine, cysteine and histidine have significant effects on the enzyme structure and action. EDTA inhibited the purified SLMDH isoenzyme indicating that SLMDH is a metalloprotein. $\beta$-mercaptoethanol and dithiothreitol didn't inhibit the SLMDH isoenzyme action indicating that thiol groups in the enzyme structure doesn't perform a job for its action. The purified SLMDH is inhibited with the N-Ethylmaleimide indicating that the enzyme contains thiol group(s) in the enzymatic reaction. A considerable resistance of the enzyme SLMDH was detected toward most of the other tested inhibitors.
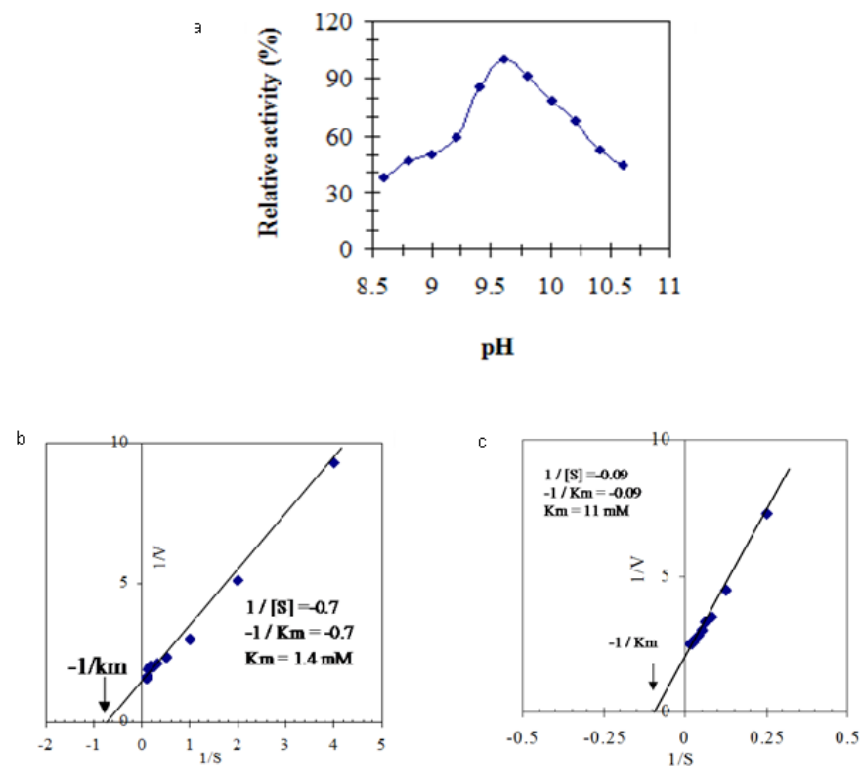

Fig. 3: (a) Effect of $\mathrm{pH}$ on the purified SLMDH using $0.05 \mathrm{M}$ glycine-NaOH buffer of various $\mathrm{pH}$ values from 8.6 to 10.6. (b) Lineweaver-Burk plot relating the reciprocal of the reaction velocity of the purified SLMDH to NAD concentration in mM. (c) Lineweaver-Burk plot relating the reciprocal of the reaction velocity of the purified SLMDH to malate concentration in $\mathrm{mM}$. 

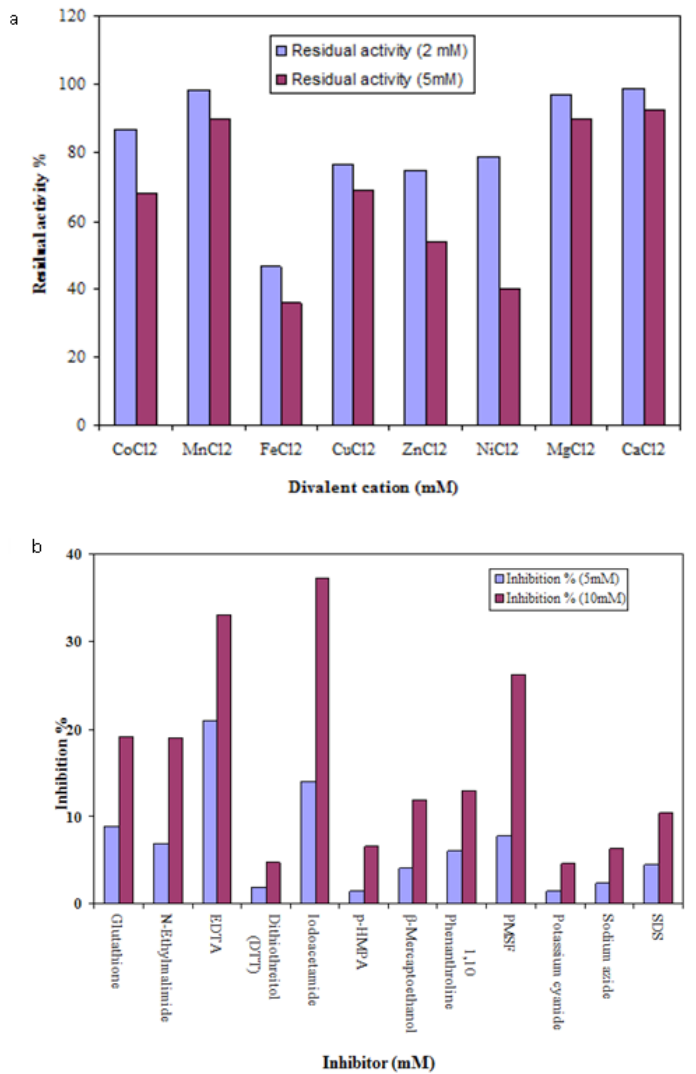

Fig. 4: (a) Effect of divalent cations on the purified sheep liver malate dehydrogenase (SLMDH). (b) Effect of inhibitors on the purified sheep liver malate dehydrogenase (SLMDH). These values represent $\%$ of the control and the means of triplicate experiments.

\section{Comparison of the constructed AST kit with the commercial-} ly available kit

The purified SLMDH is used in the construction of AST diagnostic kit. The constructed kit (prepared AST diagnostic kit with the purified SLMDS enzyme) has been compared with commercially available kit using five healthy individuals samples (1-5 samples) and twenty five patient samples (6-30 samples) (Table 2). The AST diagnostic kit is commonly used to monitor the liver function and following of various liver diseases. The prepared kit was found to be comparable to the commercial kit. The variance between the constructed and commercial kit was found more or less within the experimental error.

\section{CONCLUSION}

In conclusions, this study is the first report on sheep liver malate dehydrogenase (SLMDH). An easy, suitable and reproducible procedure is described for purification of full differentiated $\mathrm{MDH}$ from sheep liver as a local, available and rich source. The purified SLMDH enzyme is applied in the preparation of AST diagnostic kit which was found to be sensitive in comparison to a commercially kit.

\section{ACKNOWLEDGEMENTS}

This work was funded by the National Research Centre, Egypt, Agreement No. 11010403.
Table 2: Comparison of the constructed AST diagnostic kit with commercially available kit.

\begin{tabular}{|c|c|c|}
\hline \multirow[b]{2}{*}{ Serum samples } & \multicolumn{2}{|c|}{ AST (IU/L) } \\
\hline & $\begin{array}{c}\text { Constructed AST } \\
\text { Diagnostic Kit }\end{array}$ & $\begin{array}{c}\text { Commercially } \\
\text { available Kit }\end{array}$ \\
\hline 1 & 8.0 & 6.9 \\
\hline 2 & 15.7 & 16.2 \\
\hline 3 & 13.0 & 12.9 \\
\hline 4 & 17.4 & 18.9 \\
\hline 5 & 25.1 & 22.0 \\
\hline 6 & 54.9 & 50.6 \\
\hline 7 & 90.1 & 99.4 \\
\hline 8 & 37.5 & 31.2 \\
\hline 9 & 55.9 & 59.9 \\
\hline 10 & 118.2 & 110.0 \\
\hline 11 & 67.5 & 71.8 \\
\hline 12 & 40.1 & 38.2 \\
\hline 13 & 24.1 & 29.4 \\
\hline 14 & 209.5 & 216.2 \\
\hline 15 & 21.0 & 26.4 \\
\hline 16 & 78.5 & 70.6 \\
\hline 17 & 348.2 & 357.9 \\
\hline 18 & 46.1 & 43.3 \\
\hline 19 & 87.3 & 80.8 \\
\hline 20 & 33.1 & 38.9 \\
\hline 21 & 174.6 & 169.3 \\
\hline 22 & 25.6 & 28.9 \\
\hline 23 & 98.9 & 103.2 \\
\hline 24 & 696.5 & 689.4 \\
\hline 25 & 50.9 & 58.2 \\
\hline 26 & 23.2 & 20.5 \\
\hline 27 & 159.5 & 165.3 \\
\hline 28 & 69.8 & 61.7 \\
\hline 29 & 409.2 & 400.1 \\
\hline 30 & 51.0 & 57.7 \\
\hline
\end{tabular}

\section{REFERENCES}

Amarneh B, Vik SB. Direct transfer of NADH from malate dehydrogenase to complex I in Escherichia coli. Cell Biochem Biophys, 2005, 42 (3): 251-262.

Bartholomae M, Meyer F, Commichau F, Burkovski A, Hillen W, Seidel G. Complex formation between malate dehydrogenase and isocitrate dehydrogenase from Bacillus subtilis is regulated by tricarboxylic acid cycle metabolites. FEBS J, 2014, 281: 1132-1143.

Bradford MM. A rapid and sensitive method for the quantitation of microgram quantities of protein utilizing the principle of protein-dye binding. Anal Biochem, 1976, 72: 248-254.

Domenech C, Abante JJ, Bozal FX, Mazo A, Cortes A, Bozal J. An improved purification method for cytosolic malate dehydrogenase from several sources. Prep Biochem, 1988, 18: 17-35.

Fickenscher K, Scheibe R, Marcus F. Amino acid sequence similarity between malate dehydrogenases (NAD) and pea chloroplast malate dehydrogenase (NADP). Eur J Biochem, 1987, 168(3): 653-658 
Gelpi JL, Dominech C, Mazo A, Cortes A, Bozal J. Purification of malate dehydrogenase from chicken liver mitochondria, existence of a small quantity of cytosolic isoenzyme. Int J Biochem, 1988, 20: 989-996.

Genda T, Nakamatsu T, Ozaki H. Purification and characterization of malate dehydrogenase from Corynebacterium glutamicum. J Biosci Bioengin, 2003, 95: 562-566.

Gietl C. Malate dehydrogenase isoenzymes: cellular locations and role in the flow of metabolites between the cytoplasm and cell organelles. Biochim Biophys Act, 1992, 1100 (3): 217-234.

Henry JB. Clinical Diagnosis and Management by Laboratory Methods, W.B. Saunders and Co., Philadelphia, PA, 1974, 361.

Henry JB. Clinical Diagnosis and Management by Laboratory Methods, 17th ed. WB Saunders Co., 1984, 1437.

Labrou NE, Clonis YD. L-Malate dehydrogenase from Pseudomonas stutzeri: purification and characterization. Arch Biochem Biophys, 1997, 337: 103-114.

Laemmli UK. Cleavage of structural proteins during the assembly of the head of Bacteriophage T4. Nature, 1970, 227: 680-685.

Langelandsvik AS, Steen IH, Birkeland NK, Lien T. Properties and primary structure of a thermostable L-malate dehydrogenase from Archaeoglobus fulgidus. Arch Microbiol, 1997, 168 (1): 59-67.

Madern D, Zaccai G. Molecular adaptation: the malate dehydrogenase from the extreme halophilic bacterium Salinibacter ruber behaves like a nonhalophilic protein. Biochim, 2004, 86: 295-303.

Mendoza AP, Servín L, Flores ME. Malate dehydrogenase of Saccharopolyspora erythraea CA340: purification and effect of carbon source on its synthesis. Rev Lat Microbiol, 2009, 51: 18-22.

Meyer FM, Gerwig J, Hammer E, Herzberg C, Commichau FM, Völker U. Stülke J. Physical interactions between tricarboxylic acid cycle enzymes in Bacillus subtilis: evidence for a metabolon. Metab Eng, 2011, 13 (1): 18-27.

Minárik P, Tomásková N, Kollárová M, Antalík M. Malate dehydrogenases structure and function. Gen Physiol Biophys, 2002, 21 (3): 257-65.

Molenaar D, van der Rest ME, Petrović S. Bio-chemical and genetic characterization of the membrane- associated malate dehydrogenase (acceptor) from Corynebacterium glutamicum. Eur J Biochem, 1998, 254 (2): 395-403.

Nava G, Laclette JP, Bobes R, Carrero JC, Reyes-Vivas H, Enriquez-Flores S, Mendoza-Hernández G, Plancarte A. Cloning, sequencing and functional expression of cytosolic malate dehydrogenase from Taenia solium: Purification and characterization of the recombinant enzyme. Exp Parasit, 2011, 128: 217-224.

O'Farrell PH. High resolution two-dimentional electrophoresis of proteins. J Bio Chem, 1975, 250: 4007-4021.

Ohshima T, Sakuraba H. Purification and characterization of malate dehydrogenase from the phototrophic bacterium, Rhodopseudomonas capsulata. Biochim Biophys Act, 1986, 869: 171-177.

Richardson BJ, Baverstock PR, Adams M. Allozyme electrophoresis: Handbook for animal systematic and population studies. Academic press, Sydney, 1986, 201.

Sidhu NS, Delbaere LT, Sheldrick GM. Structure of a highly NADP+ specific isocitrate dehydrogenase. Act Cryst, 2011, D67: 856-869.
Singh R, Lemire J, Mailloux RJ, Appanna VD. A novel strategy involved anti-oxidative defense: the conversion of NADH into NADPH by a metabolic network. PLoS ONE, 2008, 3 (7): e2682.

Smith I. Acrylamide gel disc electrophoresis. In "Electrophoretic techniques" (Edited by Smith, I.), 1969, 365-515, Academic press, New York.

Takahashi-Iñiguez T, Aburto-Rodríguez N, Vilchis-González AL, Flores M.E. Function, kinetic properties, crystallization and regulation of microbial malate dehydrogenase. J Zhejiang Univ Sci B, 2016, 17 (4): 247-261.

Thomas L. Clinical laboratory diagnostics, Thomas, L., Ed., 1st Ed., Frankfurt: TH-Books verlagsgesellschaft; 1998, 55-65.

Thompson H, Tersteegen A, Thauer RK, Hedderich R. Two malate dehydrogenases in Methanobacterium thermoautotrophicum. Arch Microbiol, 1998, 170 (1): 38-42.

Tietz NW. Fundamentals of Clinical Chemistry. W.B. Saunder Co., Philadelphia, 1976, 682.

Trípodi KEJ, Podestá FE. Purification and characterization of an NAD-dependent malate dehydrogenase from leaves of the crassulacean acid metabolism plant Aptenia cordifolia. Plant Physiol Biochem, 2003, 41: 97-105.

Tyagi AK, Siddiqui FA, Venkitasubrsmanian TA. Studies on the purification and characterization of malate dehydrogenase from Mycobacterium Phlei. Biochim Biophys Act, 1977, 485: 255-267.

Ubuka T, Masuoka N, Yoshida S, Ishino K. Determination of isoelectric point value of 3-mercaptopyruvate sulfurtransferase by isoelectric focusing using ribonuclease A-glutathione mixed disulfides as standards. Anal Biochem, 1987, 167: 284-289.

Uttaro AD, Opperdoes FR. Characterisation of the two malate dehydrogenases from Phytomonas sp. Purification of the glycosomal isoenzyme. Mol Biochem Parasit, 1997, 89: 51-59.

Weber K, Osborn M. The reliability of molecular weight determinations by dodecyl sulfate polyacrylamide gel electrophoresis. J Biol Chem, 1969, 244: 4406-4412.

Wiseman MS, McKay D, Crow KE, Hardman MJ. Rat liver mitochondrial malate dehydrogenase: Purification, kinetic properties and role in ethanol metabolism. Arch Biochem Biophys, 1991, 290: 191-196.

Wu H, Li Z.M, Zhou L, Ye Q. Improved succinic acid production in the anaerobic culture of an Escherichia coli pflB ldhA double mutant as a result of enhanced anaplerotic activities in the preceding aerobic culture. Appl Environ Microbiol, 2007, 73 (24): 7837-7843.

Young DS. Effects of drugs on clinical laboratory tests. AACC Press, Washington, D.C., 1990.

How to cite this article:

Darwish DA, Masoud HMM, Abdel-Monsef MM, Helmy MS, Ibrahim MA. Purification and characterization of malate dehydrogenase from sheep liver (Ovis aries): Application in AST assay diagnostic kit. J App Pharm Sci, 2018; 8(02): 100-105. 